Victor Castellani

University of Denver, U.S.A.

\title{
MAKING FUN [SIC] OF HITLER
}

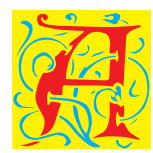

denoid Hynkel, Kaiser Overall, and Adolf Elizabeth Hitler have two things in common. First, all three names humorously identify one of the most evil people in recent or any history-no laughing matter, a moral monster responsible, directly or indirectly, for deaths of tens of millions and for misery of countless people that lasts till this today. Secondly, they also show how an artistic and, more narrowly, a satiric imagination can deal with such monstrosity.

\section{Example 1: The Great Dictator (1940)}

Even before World War 2 broke out in Europe Charlie Chaplin's film project commenced (September 1938). ${ }^{1}$ Since American producers hesitated to ridicule leadership of a country at which they were at peace, Chaplin largely self-funded the production, which was completed March 1940. Dictator was popular in the United Kingdom, inevitably, and before that across the Atlantic. It premiered in the United States October 1940, when the aerial Battle of Britain was well under way. However, despite invasions of France and the Low Countries, Denmark and Norway in spring of that year, America remained neutral politically, if not emotionally. The film reached British theaters two months later during some of the heaviest bombing of the "Blitz."

"Adenoid Hynkel" is the name under which Englishman Charlie Chaplin caustically mocked the German Führer Adolf Hitler. This evil and yet ludicrous figure is called here "The Phooey," after recently coined bit of American slang that means something like "bad luck!" "rubbish!" or the like. With "the Phooey of Tomainia” other German Nazi bigshots are associated, likewise mocked—in

1 Youtube gives online access to excepts/highlights of all three creations discussed here. For example, https://www.youtube.com/watch?v=YqyQfjDScjU (globe scene). 
one case visually by obesity and ineptitude. Their names are similarly easy to decode. Even today, in the 2010s, we know all too well those malign people whom they identify, what they stood for, and what they perpetrated in thought, word and horrendous deed: "Garbitch" equals Joseph Goebbels, an eerily sinister man, while Chaplin's fat bumbler "Herring” deflates Herman Göring. Chaplin prudently took only these names from Riefenstahl's diabolical classic glorifying record the 1934 Nazi Party rally at Nuremberg Triumph des Willens (to which Chaplin alludes visually at several places). He wisely omits others shown there, for example, grotesque Judenhetzer Nummer Eins Julius Streicher or not yet prominent wimpy-looking Heinrich Himmler. We do meet the Great Dictator's clownish colleague in tyranny "Bacterian" Duce "Benzino Napaloni," played brilliantly by American actor Jack Oakie with nice-a EEtahlian accent. These names deploy: [1] comical sounds, such as Anglophone comedians know to be intrinsically funny ("Hynckel": think of "Twinkie" and "tickle"); [2] amusing and belittling wordplays: "Adenoid," a throat tissue, apt for a screaming rabble-rouser; "Garbitsch," for trash as well as bitch; "Herring," for small fish. Duce "Benzino," motor fuel, from a land already famous for sports cars. "Napaloni" suggests at once a wouldbe Napoleon and the pastry named "napoleon" and either pasta or Italian dessert: maccaroni and types rigatoni and cannelloni or else spumonelspumoni. "Tomainia" and "Bacteria," naming the two Axis nations, indicate poison and disease.

Repeated quotation of the lovely Prelude to Lohengrin intrigues us, first during a famous delicately grotesque sequence when Hynckel cavorts with a big globe-balloon, tossing and kicking it up, then when it returns during the dreamy moment of hope at the very end. ${ }^{2}$ For Chaplin, Richard Wagner seems both Mr. Hyde and Dr. Jeckel. Germany's cultural achievements can hardly be denied, sour though Hitler renders her music by appropriating Bayreuth and the composer's grandsons.

Chaplin and his audiences knew about random "wildcat" killings of Jews and institutional humiliations, about "concentrations" of them as also of dissidents and other categories of un-person. However, when "Herring" gleefully announces invention of a new poison gas, audiences in 1940-41 suspected that, like other inventions that fatso celebrates, this is another fiasco, whereas we, shuddering at mention of "gas," must remind ourselves that horrors of Vernichtungslager were in 1940 inconceivable (unless to the likes of Himmler), that the Wannseekonferenz was two years in the future.

\footnotetext{
2 To be reminded of this, visit: https://www.youtube.com/watch?v=6Jggiq2uXu0
} 
Dictator includes much sheer clowning. Hynkel at times switches from dialogue in unmarked English to ludicrous "Tomainian" accent. Chaplin plays Hynkel both ways, mixing the ludicrous with the ominously serious. The preposterous plot contrives the undetected substitution for Hynkel of a lookalike WW1 veteran Jewish barber, whom of course Chaplin also impersonates. Along our way to this improbability several hilarious scenes with Hynkel, some in slap-stick vein, have amused us. One memorable sequence confronts Hynkel and Napaloni, childish, farcical rivals for superior dignity that neither can rightly claim.

The deliberately nameless barber, an Everyman or at least an everyday decent person, hesitantly ascends to the microphone on the Phooey's exalted podium and delivers a famous, widely excerpted and transcribed speech in Chaplin' own normal voice. This follows and gainsays a harsh harangue by Garbitsch before citizens of newly annexed "Osterlich." At first calm, then agitated and passionate the barber urges peace and human solidarity on an astonished audience, thousands in person, millions in the radio. Until this point shrewd interplay of harsh realism with comedy works. The end of the movie, however, is more preachy than effective, noble in sentiment yet incongruous after all that came before. "The movie plays like a comedy followed by an editorial," American film critic Roger Ebert wrote in 2007. ${ }^{3}$ Satire here has turned dark in Garbitch's speech, where grimacing parody needs only slightest exaggeration. Then, in the barber's speech, humor is shelved. The broader travesties have more impact today than the movie's concluding wishful, wistful thought that Hitler might somehow be neutralized, that compatriots who would conspire against him and persuade the German people to change their course-so that Wagner no longer hurt the mind.

\section{Example 2: Der Kaiser von Atlantis (1943-44)}

The author of the libretto for one-act opera Der Kaiser von Atlantis, oder Die Tod-Verweigerung (i.e., "Death's Boycott") was the poet Peter Kien, while Victor Ullmann composed its musical score. ${ }^{4}$ Both were "racial" Jewish inmates at a showcase Konzentrationslager in occupied Czechoslovakia. Theresienstadt (Terezín) was designed to demonstrate to International Red

\footnotetext{
${ }^{3}$ Ebert's entire essay: http://www.rogerebert.com/reviews/great-movie-the-great-dictator- 1940

4 The complete opera: https://vimeo.com/45899028
} 
Cross inspectors how conditions in such places were not unpleasant, in particular how culture flourished there. The Ullmann-Kien piece was created there beginning in 1943 and nearly produced the following year-when censors suddenly realized how ambiguously it referred to Hitler, to Wehrmacht and SS, and to the "total war" that Joseph Goebbels had announced in February 1943. The poetic concept of this work is complex and elusive. A musician-censor may have taken offense when Overall is introduced to a sour, distorted variation of the Deutschlandlied, then winced at a sweetly lugubrious parody of Luther's chorale Ein' feste Burg, here hymning not unser Gott but Death, "Komm' Tod, du unser werter Gast" ending the opera. This is reminds one of the Weill-Brecht Dreigroschenoper's caustic mockery of "pious" hymns.

The second half of 1943 and early '44 brought about Germany's retreat on southern and eastern fronts, bombing day and night of its big and medium-sized cities, and much more bad news. No 1944er "springtime for Hitler" came after; instead a July Plot threatened his sad life. Shortages of everything that Chaplin hopefully imagined four years earlier Germans now experienced for real. Despite the increasingly desperate military situation, extermination camps were in full swing. Librettist and composer were soon transported, with tens of thousands besides, to Auschwitz and died there by the end of 1944, Kien of disease, Ullmann, more likely, gassed.

The plot of their opera improbably postulates a complete suspension of death because Death Himself cannot keep up with the mechanized slaughter of the $20^{\text {th }}$ century. Tod (a role scored for bass-baritone) sings that he was content with old-fashioned warfare, but not with the massive industrial carnage of its 20th-century version. He needs a respite! What further concerns us here is the extraordinary dark optimism of the work that emerges incongruously after the first two of its four Bilder, "scenes." For this short opera shares a wishful conclusion with Chaplin's long movie (which two prisoners in Poland can hardly have seen, though perhaps they knew about it).

Unlike historical Hitler, absolute ruler of an imperialist Reich, their title character does not disdain the title "Kaiser." Indeed the Emperor's (English) name "Overall" transparently translates "über alles" as in the German national anthem. Could the creators of the work know either the workman's or farmer's attire called "overalls" in American English or the British laborer's smock of that name? If so, it refers sardonically to the "Arbeiter" element in the name of the National Socialist German Workers' Party. 
With manifest global ambitions like Garbitsch's and Hynkel's, Kaiser Overall sends troops tanks and aircraft to conquer the world. Abruptly in Bild 4, however, he has a change of heart. Its motivation is problematic, for its occasion is that astonishing, frustrating cessation of Tod. Human deaths come to a complete halt, since Death will not allow any of the empire's enemies, nor any of its own fighters, to die-none. Increasingly frantic attempts to hang, shoot, or otherwise dispatch an attempted assassin of the Emperor get nowhere. Comic frustration ensues. Overall's first response exaggerates only a little what followed assorted Attentaten against the German Führer. He triples his personal fortified security and energetically prosecutes the "war of all against all" that Der Trommler announced in Bild 1. ${ }^{5}$ Cynically he declares that he is imparting the secret of immortality to his troops. The enemy, however, are likewise un-killable. The Drummer tries to incite two soldiers, on opposite sides, to fight; however, one of them turns out to be female. They would rather make love than war. Furthermore, wistfully recalling peacetime, they ignore the Drummer's most violent drumming. Parody, even mockery is involved here as in Chaplin's film, and ludicrous frustration, though it is less clownish here than in Dictator. Perhaps that is why it took censors so long to arrest it. Its ending, in two variants, amounts to this: instead of offering the German people as a sacrifice to himself and his catastrophic megalomania, as Hitler was doing during the last months of his life-pretty obviously the case by mid-1944, Overall offers himself as appeasement to Death, who readily accepts him. This makes amends for the ugly slaughter that led Death to boycott armed conflict. Overall's death may even, we sense, permit that post-WW1 peace to be restored which he had scorned and violated.

Death will still need to hold off awhile. People need to be reacquainted with life-love and wine, beautiful landscape without bomb craters. Only when they have such life does death recover its proper meaning. By the bold premise of the opera their living lately has been worse than death, a metaphorical lifeless state without death's closure, for example, in the peculiar plight of trained warriors who can neither kill nor die. Overall's solitary death will restore proper death and life. Alas, "Atlantis," the name of the realm that the Kaiser will leave behind, may indicate despair over whether the Nazi Reich can avoid the fate of Plato's doomed mythic island.

5 Because "Der Trommler" is scored for a female voice, discussions in English mention a "Drummer Girl." It seems to me that a Hitlerjugend-type adolescent boy is intended. 
Example 3: The Producers (initially 1968)

Mel Brooks was born in Brooklyn New York of German-Jewish and Russian-Jewish parents. Perhaps his most controversial creation, The Producers has had three incarnations. First it was a movie starring Zero Mostel. Years later it was made into a highly awarded live musical (2001), which was made into a movie (2004). Nathan Lane starred in both of these. Both Mostel and Lane played Broadway producer Max Bialystock, the has-been "King of Broadway" whose recent musicals have failed. He and his accountant Leo Bloom accidentally realize that a spectacular failure could be lucrative. Backers underwriting it could safely be promised — dishonestly, yet safely—many times a total hundred percent of shares, if it was guaranteed to fail, because shares would have value only if it was a profitable hit. Max and Leo find a perfectly awful musical titled Springtime for Hitler. ${ }^{6}$ A Nazi-not Neo-Nazi, but an undetected, unrepentant Nazi named Franz Liebkind-created the most abominable possible book and music. Celebrating the glories of the Third Reich and idolizing "Adolf Elizabeth Hitler," it choreographs storm-troopers dancing in swastika formation to the tritest imaginable music. Max and Leo learn, appalled, that Liebkind takes his wretched creation seriously; they see only sure-fire F-L-O-P. No way could it succeed! "We knew we couldn't lose," Max laments later, "half the audience were Jews!" Lose they nevertheless do-by succeeding. Some of the audience walk out indignantly at intermission, other after. Those who stay, however, if only to get their expensive tickets' worth, come to understand it—misunderstand it according to its author's and producers' intentions - as brilliant uproarious satire. ${ }^{8}$

Brooks was a young adult when the full extent of Nazi atrocities became widely known. He suffered no dread of possible German victory as Chaplin certainly did, nor personal danger of genocidal murder like Kien and Ullmann. Unsurprisingly, therefore, Brooks endured grim rebuke over making fun of Blitzkrieg ("Springtime for Hitler and Germany [dah-da-DAH-da], winter for Poland and France") and for his movies' and musical play's silence about the Holocaust.

${ }^{6}$ Visit: https://www.youtube.com/watch?v=kHmYIo7bcUw (1968 movie’s chorus) and http://www.dailymotion.com/video/x2lu0ef (Broadway show's chorus + Hitler).

7 "Descended from a long line of English kveens," Franz explains when administering the "Sacred Siegfried Ohss" to the producers.

8 Broadway economics and theater culture are also satirized, since "Springtime" is satire-within-satire. The brazen crookedness of overselling shares subjects Max to criminal prosecution and conviction in Act Two! 
A passionate minority of persons, not only but chiefly Jewish Americanssome who barely escaped the Holocaust but lost family and friends, were and many remain horrified that a Jew like Brooks, or anyone at all, could make fun (and money) out of Hitler. They agree with those inside the play's/film's action who leave angrily after Act One. These critics, like Chaplin's in the early 1940s, missed the point of satire. Like Chaplin, to whom he acknowledges indebtedness, Brooks is not a historian, but a comic parodist-satirist.

A majority, on the other hand, agree with opening night playgoers who stayed in the theater opening night, determining that "Springtime" is an response to the indelible memory of Hitler in a world that still contains neo-Franz Liebkinds. Interviewed by Der Spiegel in 2006, when the DVD of the musical entered worldwide distribution, Brooks said, "Of course it is impossible to take revenge for 6 million murdered Jews. But by using the medium of comedy, we can try to rob Hitler of his posthumous power and myths. In doing so, we should remember that Hitler did have some talents. He was able to fool an entire population into letting him be their leader." In 2015 the online Jewish magazine Tablet reported on Producers: "As Brooks has often explained, he saw it as his goal to mock Hitler. 'You can't get on a soapbox with these orators, because they're very good at convincing the masses they're right,' he said in an interview. 'But if you can make them look ridiculous, then you can win over the people.' If he was going to go toe to toe with Hitler, he had to rely on the only weapon he had to annihilate his opponent: comedy." ${ }^{10}$ Hitler's lyric "Heil myself, heil to me, I'm the kraut Who's out to change our history. Raise your hand, There's no greater Dictator in the land!" does this. Some things are indeed too grim to make fun of. Nevertheless villains responsible for horrors can be attacked not only by dour damnatio memoriae but by posthumous ludibrium, by scornful reduction to farce.

Wit and humor lose penetrating impact if their thrust is either too needle-like or too blunt. Despite its multiple targets Brooks' satire packs more punch than both the older movie, which is too obviously tendentious (most

9 See: http://www.spiegel.de/international/spiegel/spiegel-interview-with-mel-brooks-with-comedy-we-can-rob-hitler-of-his-posthumous-power-a-406268.html

${ }_{10}$ Visit: http://www.tabletmag.com/scroll/192439/dont-forget-to-laugh; see now also http://www.tabletmag.com/jewish-arts-and-culture/206140/a-conversation-with-mel-brooks 
people see it—once!), and the opera which, more poignant than pointed, weakens it comic vigor by embitterment or at least pensiveness, and whose exact message is somewhat obscure. Neither of its alternative endings is quite satisfying. All three works use distorted imitation - that is, parody. Chaplin parodies Triumph of the Will and newsreels, Kien and Ullman German music and Nazi brow-beating. Brooks takes on entertainment genres and a broader culture of propaganda because "All you need to know is, Everything is showbiz." All three works use absurd exaggeration, which in satire should be not complete fabrication but ridicules by distortion. All present and develop diverse incongruities, as comedy must. Anglophones Chaplin and Brooks use accents and verbal humor. Brooks and Ullmann deploy musical take-offs. The almost-pretty chorale concluding Kaiser recalls, as already noted, pseudo-religious hypocrisies in Dreigroschenoper, whereas "Springtime" spoofs frivolous, upbeat American patriotic musicals almost as jingoistic and quite as cheerfully oblivious of real life in stressful times. Chaplin engages Wagner in a very different mode.

Admirers of humorists who pillory outrageous public figures, demagoguery, and cultural shibboleths may question the un-comical wishful, hopeful endings of Dictator and of Kaiser, respectively, when the Jewish barber, posing as Hynkel, unspeaks Hitler's appalling ideology in a painfully earnest speech, when Emperor Overall appeases Death so death and life may resume their proper alternation for humankind. Those are frowning incongruities. From Brooks' distant post-V Day perspective he knows better than to suggest a peaceful end to the Third Reich. On the other hand, toward the end of his masterpiece Blazing Saddles (1974) he makes fun of Hitler's suicide. During a movie studio's cafeteria lunch an actor costumed and made up as Hitler say matter-of-factly, in a big-city American accent, "They lose me right after the bunker scene" for the end of his current employment. This is both funnier and more telling than Hynkel's implausible mistaken arrest in the Chaplin film that permits a Jew to impersonate him or Overall's startling self-sacrifice. 